\title{
APPLICABILITY OF THE MEDICATION LEVEL VARIABILITY INDEX (MLVI) IN ADULT HEPATIC TRANSPLANTATION AND ASSOCIATION WITH GRAFT REJECTION RATES
}

\section{Aplicabilidade do índice de variação do medicamento (MLVI) em Transplante hepático de adultos e associação com taxas de rejeição do enxerto}

\author{
Yakime de Brito Adrião, Mário Reis Álvares da Silva, Alexandre de Araújo, Soraia Arruda, \\ Paola Hoff Alves
}

\begin{abstract}
Introduction: Calculation of the Tacrolimus variation index by using the MLVI (Medication Level Variability Index) is set in pediatric liver transplant patients, and it is useful in controlling treatment adherence by associating MLVI values $>2.5$ to acute graft liver rejection. Purpose: To verify the association between MLVI values and rejection in adult liver transplant patients. Methods: A retrospective cohort study including liver transplant patients over 18 years of age from December 2012 to December 2017 using orally tacrolimus. For MLVI calculation, tacrolimus serum level outpatient samples were used after 1 year of transplantation. Results: A total of 125 patients were transplanted, of which 86 met criteria for inclusion in the study. The most frequent reason for transplantation was $\mathrm{C}$ virus infection $(55.8 \%, n=48)$. Rejection was identified in $18.6 \%$ of patients $(n=16)$. The mean MLVI among rejection and nonrejection patients was 2.5 and 2.1 respectively $(R R=0.95, C l: 0.4-2.1, p=0.57)$. The frequency of non-immunological complications was $56.2 \%(n=9)$ in patients with rejection versus $62.8 \%(n=44)$ in patients without rejection, most of them with recurrence of virus $C(56,8 \%, n=25)$. Conclusion: Although the mean value of MLVI was higher in patients with rejection, our data showed no statistical difference between both groups, which differs from previous studies in pediatric patients. A higher number of nonimmune complications were observed in patients without rejection. The findings suggest that new MLVI cutoffs should be explored in the adult population.
\end{abstract}

Keywords: Liver Transplantation; Tacrolimus; Graft Rejection.

Institution:

Departamento de Farmácia Clínica do Hospital de Clínicas de Porto Alegre - Porto Alegre/RS - Brasil

\section{Correspondence:}

Paola Hoff Alves

E-mail: phoffalves@hcpa.edu.br

https://doi.org/10.53855/bjt.v24i2.009

Received: 26/01/2021

Accepted: $27 / 04 / 2021$

\section{INTRODUCTION}

According to the Brazilian Organ Transplant Association (2018), in the Brazilian Registry of Transplants until June 2018, the liver was the second most transplanted organ in Brazil (1087 transplants), being the first place occupied by the kidney (2858 transplants), with a $2.6 \%$ increase in liver transplants, when compared to 2017. Indicated in cases of cirrhosis - whether for autoimmune reasons or not, acute liver failure, chronic liver failure, some metabolic disorders and hepatocellular carcinoma, liver transplantation is the last treatment option available, requiring commitment from its candidates, since the number of organs offered for donation does not meet the current demand - in Brazil, until June 2018, a total 
of 1527 candidates for transplant were placed on the waiting list of liver disease; however 409 of these died while waiting for an organ. ${ }^{1-3}$

Transplantation of solid organs involves the almost lifelong use of immunosuppressive therapy and other drugs to maintain the health of the graft and to prevent serious associated complications. ${ }^{4}$ In order to reduce or inhibit the immune response from the recipient to alloantigens present in the transplanted organ of the donor, immunosuppressive drugs act at different sites in the $\mathrm{T}$ cell cascade, which are therefore classified into Calcineurin inhibitors (inhibit IL-2 synthesis), Purine Synthesis Inhibitors (inhibit nucleic acid synthesis), Enzyme Inhibitors Mammalian target of ripamicyn mTOR (inhibit the proliferation signal of smooth muscle cell growth and hematopoietic lines) and corticosteroids (act at several levels in the cascade). ${ }^{5} \mathrm{~T}$ cells are known to play a central role in the response adaptive or acquired immune system, where, after its activation, production and the release of soluble molecules that aim to combat the antigen, in this case, the transplanted organ (implant). ${ }^{6}$

Adherence to immunosuppressive drugs is extremely important since they reduce the risk for acute and chronic rejection episodes, in addition to being associated with a better quality of life for its supporters. ${ }^{5,7-9}$ Signs of non-adherence may be represented by the presence of tremor, neurotoxicity and renal failure, which can be one of the causes of graft rejection. ${ }^{7,10-18}$

In outpatient follow-up of transplanted patients, the collection of blood tests, mainly of the serum tacrolimus level is standard routine and a sometimes sudden variation of these levels is frequently observed. The degree of variation of this test can be assessed by calculating the standard deviation of consecutive serum tacrolimus levels for the same patient, and it is denominated Drug Level Variability Index (MLVI). ${ }^{19}$ Such index is already well established in studies with pediatric patients, being used to monitor adherence to treatment, associating high amounts of MLVI, that is, high fluctuation of serum tacrolimus levels to acute rejection of the liver graft. ${ }^{10,11,13-16}$ In adults, however, there are few studies associating the MLVI method with graft rejection. ${ }^{20}$ The calculation of the tacrolimus variation index through MLVI can be useful in preventing graft rejection, since it allows the early detection of poor adherence and the consequent development of strategies to the team to rescue the compliance of the patient.

Therefore, the objective of the present study is to assess whether patients with MLVI> 2.5, considered non-adherent to immunosuppressive therapy have greater complications related to the graft after 1 year of transplantation.

\section{METHODS}

This is a retrospective cohort study carried out at Hospital de Clínicas de Porto Alegre through the analysis of medical records.

The study included liver transplanted adult patients between December 2012 and December 2017 who met the following inclusion criteria: over 18 years of age using oral tacrolimus capsule for maintenance of immunosuppression for more than a year and with at least three measurements of serum tacrolimus level on an outpatient basis over an 1 year interval. The following were excluded: liver re-transplanted patients, patients transplanted of other organs, patients with no conditions of oral drug use and / or with no cognitive conditions, death before completing one year of treatment / followup or who have lost clinical follow-up.

Through the medical record review, variables containing information related to demographic data (sex and age at the time of transplantation), underlying disease (indication for transplantation), date of transplantation, non-immunological complications related to the graft, episode of acute and / or chronic rejection confirmed by biopsy, ambulatory serum levels of Tacrolimus and MLVI value of each patient were assessed. Serum levels collected along the periods of hospitalization were excluded, and the MLVI was calculated by using the standard deviation of the remaining serum levels of each patient. The sample was dichotomously analyzed as well, in a group with MLVI> 2.5 and $M L V I \leq 2.5$.

Continuous variables were described as mean \pm standard deviation or median $(25 \%-75 \%)$, according to distribution. Categorical variables were described in absolute (n) and relative (\%) frequency. In order to compare adherent and non-adherent groups regarding the risk of rejection and other complications, the chisquare test was used. Multivariate regression analysis was used to assess the association between MLVI> 2.5 and graft complications, which were adjusted for possible confounders (age, sex, underlying disease). To determine the predictive value of the MLVI (or cut-off point), a ROC curve (Receiver Operating Characteristic Curve) was constructed. Collected data were analyzed by using the statistical software Statistical Package For Social Sciences (SPSS) version 18.0.

Data collection from medical records was carried out after approved by the Research Ethics Committee of Hospital de Clínicas de Porto Alegre.

As this is an observational and retrospective study with no intervention to drug therapy, the application of the Free and Informed Consent Term is waived. 


\section{RESULTS}

In total, 125 liver transplants were performed from January 2012 to December 2017. Patients with less than 3 measurements of serum tacrolimus level $(n=13)$, retransplanted $(n=2)$ and dead were excluded from the study before completing 1 year of transplantation ( $n$ $=24$ ), totaling a sample of 86 patients included in the study. (Figure 1)

Figure 1. Process of selecting participants in the study.

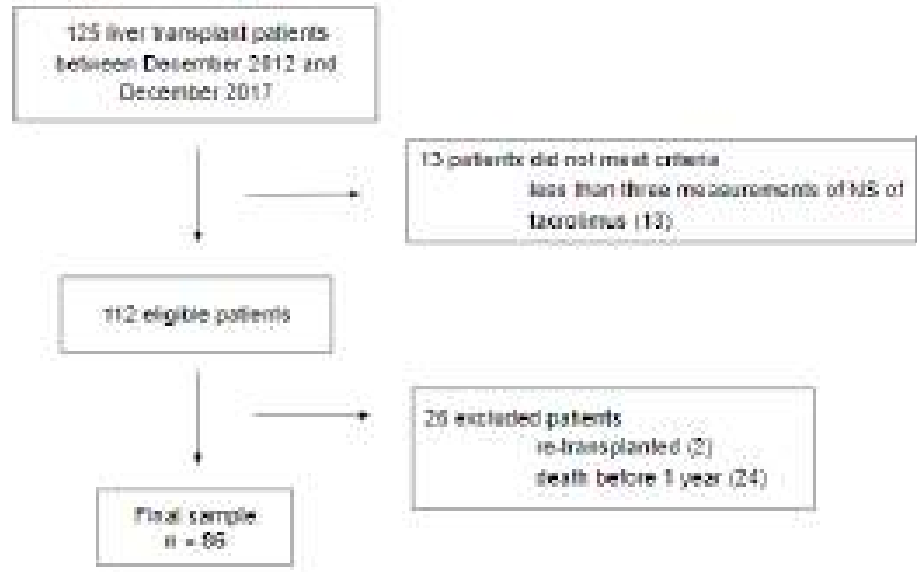

The mean age of patients was $56.7 \pm 7.2$ years, mostly male (64\%). The most frequent causes for transplantation were due to infection by virus C (68.6\%), associated or not to the alcohol factor. The mean MLVI value of the total population was 2.2. The mean value of MLVI was 3.7 and 1.5 in patients with MLVI> 2.5 and $\leq 2.5$, respectively. Rejection after 1 year of transplantation was identified in $18.6 \%(n=16)$ of patients, where the average time from the date of transplantation to the biopsy-confirmed rejection episode was 2.2 years (809 days). Non-immunological complications were observed in $61.6 \%(n=53)$, being the most frequent infection by $\mathrm{C}$ virus $(\mathrm{n}=22 ; 54.7 \%)$, followed by bile duct complications (20.8\%), both associated or not with other complications (Tables 1 and 2). To analyze the results, the sample was classified into two groups: $M L V I>2.5$ and $M L V I \leq 2.5$.

\section{Association between MLVI values, rejection and non-immunological complications}

The distribution of cut-off values for MLVI by the presence of rejection is shown in Figure 2. Twenty-eight patients $(32.6 \%)$ obtained an MLVI value $>2.5$ and of these, $18 \%$ had a diagnosis of graft rejection after 1-year treatment with tacrolimus. In patients with MLVI $\leq 2.5$ (67.4\%), the occurrence of rejection was $19 \%$.
In order to search for MLVI values associated to rejection, a ROC curve was constructed as an analytical prediction model (Figure 3); however, significant MLVI cutoff values were not detected for sensitivity and specificity points.

When analyzing MLVI values and the occurrence or not of rejection in the studied population, it was observed that greater than 1 and less than 2 MLVI values were more frequent to the occurrence of rejection (Figure 4).

Patients with MLVI> 2.5 had a rate of non-immunological complications of $35.7 \%(n=10)$, whereas in patients with $M L V I \leq 2.5$, the rate was $74.1 \%(\mathrm{~N}=43)$.

Table 1: Characteristics of the population

\begin{tabular}{lc}
\hline \multicolumn{1}{c}{ Total of Patients } & $\mathbf{n}=86$ \\
\hline Middle Ages & 56,7 years \\
Sex & \\
Male & $55(64 \%$ \\
Reason for transplant & \\
Hepatite C & $48(55,8 \%)$ \\
Hepatitis + alcohol & $11(12,8 \%)$ \\
Hepatitis B & $4(4,7 \%)$ \\
Non-alcoholic Fatty Lives Disease & $4(4,7 \%)$ \\
Alcohol & $3(3,5 \%)$ \\
Primary Sclerosing Cholangitis & $3(3,5 \%)$ \\
Cryptogenic & $3(3,5 \%)$ \\
Auroimmune hepatits & $1(1,2 \%)$ \\
Alpha 1 deficiency Antitrypaim & $1(1,2 \%)$ \\
Glycogenosis & $1(1,2 \%)$ \\
Neuroendocrine Tumor Metastasis & $1(1,2 \%)$ \\
Primary Biliary Cirrhosis & $1(1,2 \%)$ \\
Severe Acute Liver Failure & $1(1,2 \%)$ \\
Hepatitis C + Alcohol + Hepatitis B & $1(1,2 \%)$ \\
Others & $1(1,2 \%)$ \\
\hline
\end{tabular}

Table 2 - Characteristics of the post-transplant population

\begin{tabular}{lc}
\hline $\begin{array}{l}\text { Non-immunological complications after } \mathbf{1} \\
\text { year of transplant }\end{array}$ & $\mathbf{n}=\mathbf{5 3}$ \\
\hline Hepatitis C & $29(54,7 \%)$ \\
Bile duct complications * & $11(20,8 \%)$ \\
Neoplasms * & $7(13,2 \%)$ \\
Metabolic Syndrome * & $7(13,2 \%)$ \\
Others & $29(54,7 \%)$ \\
Rejection after 1 year of thansplant & \\
No & $70(81,4 \%)$ \\
Yes & $16(18,6 \%)$ \\
\hline * Associates or npt woth complications; $n=$ total number
\end{tabular}


Association between MLVI values, rejection and nonimmunological complications

The distribution of cut-off values for MLVI by the presence of rejection is shown in Figure 2. Twentyeight patients (32.6\%) obtained an MLVI value> 2.5 and of these, $18 \%$ had a diagnosis of graft rejection after 1 -year treatment with tacrolimus. In patients with MLVI $\leq$ $2.5(67.4 \%)$, the occurrence of rejection was $19 \%$.

In order to search for MLVI values associated to rejection, a ROC curve was constructed as an analytical prediction model (Figure 3); however, significant MLVI cutoff values were not detected for sensitivity and specificity points.

When analyzing MLVI values and the occurrence or not of rejection in the studied population, it was observed that greater than 1 and less than 2 MLVI values were more frequent to the occurrence of rejection (Figure 4).

Figure 2: Acute rejection after one year of transplantation: comparison between patients with $M L V I \leq 2.5$ and $M L V I>2.5$

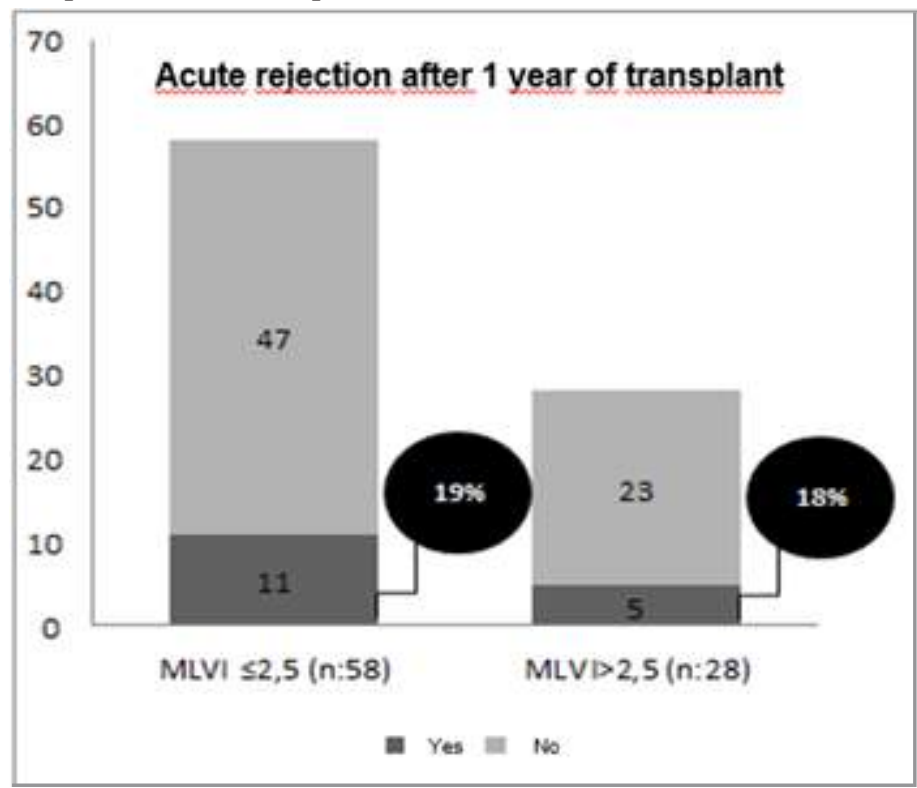

MLVI = Medication Level Variability Index; $n=$ Total number.

Association between non-immunological complications, underlying disease and rejection

In patients who had $C$ virus infection as basic disease (alone or associated with alcohol), it was observed that a total of $49 \%$ had disease relapse after transplantation. In addition, the rejection rate was $14 \%$ versus $20 \%$ of those who did not have recurrence of the disease.

Upon analyzing the groups with MLVI> 2.5 and $\leq 2.5$, infection with virus $C$ was observed as the most frequent, both as basic disease (70\% and $62.8 \%$, respectively) and as a non-immunological complication ( $40 \%$ and $58 \%$, respectively).
Figure 3: ROC curve (AUC .536)

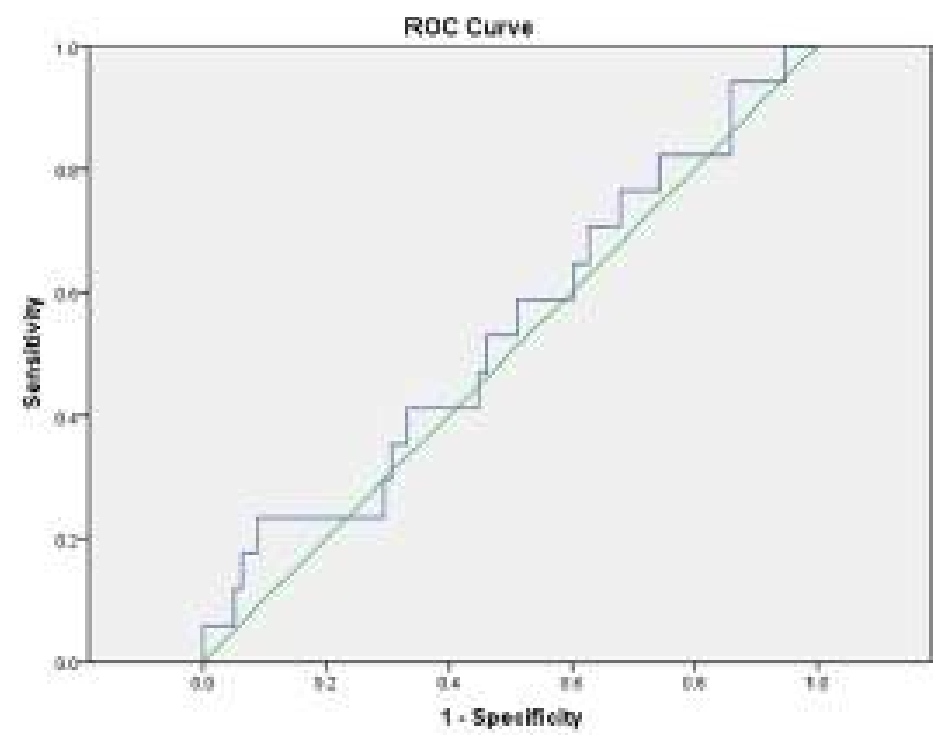

ROC curve (Receiver Operating Characteristic) relating the values of MLVI (Medication Level Variability Index) and rejection.

Figure 4: Distribution of MLVI values due to the presence of rejection.

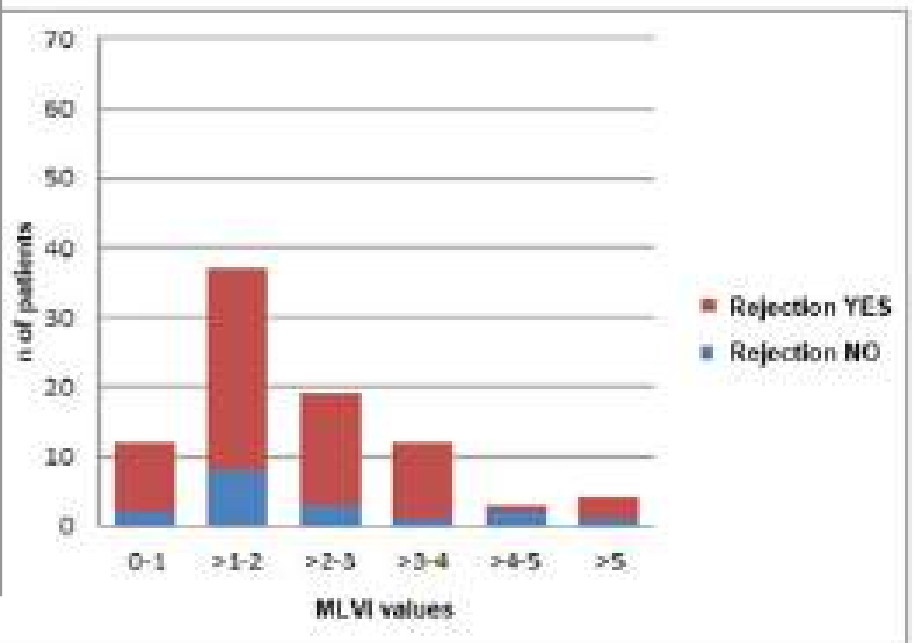

$M L V I=$ Medication Level Variability Index; $n=$ Total number .

\section{DISCUSSION}

Few studies have assessed the association between MLVI values and graft complications in adult liver transplant patients. ${ }^{15,20-22}$ With regard to Brazilian publications, only one addresses the subject covering the pediatric population. ${ }^{23}$ The MLVI index has been already used to monitor adherence to treatment by associating high MLVI values with acute liver graft rejection. ${ }^{10,11,13-16}$ 
Our study has a sample of 86 adult liver transplanted patients, where the main purpose was to assess the predictive value of MLVI> 2.5 against graft rejection, and to verify the association with non-immunological complications. In a retrospective analysis carried out by Supelana et al, 2014, it was found that MLVI values of 2.52.6 were associated to rejection of the liver graft, while values between 1.8-2.0 could predict it. ${ }^{15}$ In the present study, the value of MLVI > 2.5 showed no association to rejection ( $p=0.576$; RR: $0.95 ; \mathrm{Cl}: 0.4-2.1$ ). However, it is possible to verify the association between MLVI values $\leq 2.5$ and non-immunological complications $(p=0.0007$; RR: $0.34 ; \mathrm{Cl}: 0.18-0.65)$. In an attempt to explain why graft rejection was the majority $(20 \%)$ in the studied population that did not suffer from $C$ virus relapse, in a study conducted by Araújo et al, 2019 assessing the treatment of patients with recurrent $C$ virus after liver transplantation, it was argued that the treatment of those patients could contribute to make the immune system more active. The hypothesis of lymphocytic exhaustion induced by virus $C$ was considered, which would be restored after treatment, and therefore, those patients would be more susceptible to the occurrence of rejection. ${ }^{24}$ However, in a study by Saxena et al, 2017 also assessing the treatment of hepatitis $C$ in transplant recipients, the rate of acute rejection was similar to that found in patients after transplantation who were not treating $\mathrm{HCV} .{ }^{25}$

When comparing adherence to treatment with immunosuppressant between young adults and elderly liver transplanted recipients, Leven et al, 2017 found better adherence in the elderly ( $\geq 65$ years), in addition to noting that they did not have an increased risk for rejection. ${ }^{20}$ Comprising a population of \pm 56.7 years, therefore considered elderly, the present study may have been influenced by good adherence, showing lower than expected MLVI values (mean 2.2). ${ }^{20}$ Also, in a retrospective study with transplanted patients, Schweizer et al, 1990 found a higher likelihood of nonadherence in young people, just as Greenstein et al, in 1998 found greater drug adherence in kidney transplant patients from 40 years of age on..$^{26-27}$

Taking into account the underlying disease of liver transplanted patients, there are differences between pediatric and adult patients. While one of the biggest causes for pediatric transplantation is biliary atresia, a disease where there is involvement of the bile ducts that can lead to liver cirrhosis in adults, one of the main causes for transplantation in the world is due to infection by the virus $\mathrm{C}$, where the recurrence of the disease is universal, a study shows that virus particles can still be found in the serum of the recipient, even after the liver transplantation. ${ }^{28-32}$ Therefore, considering the underlying disease factor, and that in the pediatric population, the immunosuppressive therapy is mostly handled by parents, we understand that the use of MLVI would have a better correlation with rejection due to the poor adherence in this population. In the adult population, according to our data, it was not able to influence alone the outcome in question (rejection), probably due to the important characteristic of the underlying disease motivating the transplant. In addition, the control of the drug therapy in adult patients is highly variable, with many factors that would influence adherence, among which we can mention: personality of the patient, schooling, understanding of the disease, family support, among others, as shown by a study conducted by Burra et al, 2017. ${ }^{33}$

Our work has some limitations. The first one is related to the type of the study: cohort studies are subject to loss of follow-up, and this can impact the sample size and consequent statistical strength for association with the outcome, in addition to not being able to control all confounding factors. Additionally, we consider the limiting factor of the study being conducted in a single center. The small sample size is also recognized, perhaps unable to support the hypothesis of graft rejection prevalence in patients with MLVI> 2.5. Since there is no gold standard method for assessing drug adherence, we understand that other tools could have been used to improve its assessment, and consequently predicting its impacts. To strengthen with regard to the indication of transplantation, our sample reflects the adult liver transplant population in the world, in addition to being one of the few studies assessing the MLVI tool on them.

\section{CONCLUSION}

Our data suggest that MLVI used as a drug adherence tool and as a method of predicting acute rejection in liver transplanted recipients may not be applicable as an isolated model in adult patients. Further work is required to review the subject, as well as the development of higher medication adherence tools to assist the clinical team in the prevention or early detection of acute graft rejection in this population. 


\section{RESUMO}

Introducão: O cálculo do índice de variação de tacrolimo através do MLVI (Medication Level Variability Index) está estabelecido em pacientes pediátricos transplantados de fígado, sendo útil no controle da adesão ao tratamento, associando valores de MLVI> 2,5 com rejeição hepática aguda do enxerto. Objetivo: Verificar a associação entre os valores de MLVI e rejeição em pacientes transplantados de fígado adultos. Métodos: Estudo de coorte retrospectivo incluindo pacientes transplantados hepáticos maiores de 18 anos, de dezembro de 2012 a dezembro de 2017, em uso de tacrolimus por via oral. Para cálculo do MLVI, amostras ambulatoriais de nível sérico de tacrolimus foram usadas após um ano do transplante. Resultados: Foram transplantados 125 pacientes, dos quais 86 atenderam aos critérios de inclusão no estudo. O motivo mais frequente para o transplante foi infecção pelo vírus $C(55,8 \%, n=48)$. Rejeição foi identificada em $18,6 \%$ dos pacientes $(n=16)$. A média de MLVI entre pacientes com rejeição e sem rejeição foi de 2,5 e 2,1, respectivamente $(R R=0,95, I C: 0,4-2,1, p=0,57)$. A frequência de complicações não imunológicas foi de $56,2 \%(n=9)$ em pacientes com rejeição versus $62,8 \%(n=44)$ em pacientes sem rejeição, a maioria deles com recorrência do vírus C $(56,8 \%, n=25)$. Conclusão: Embora o valor médio do $M L V I$ tenha sido maior nos pacientes com rejeição, nossos dados não mostraram diferença estatística entre os dois grupos, o que difere de estudos anteriores em pacientes pediátricos. Maior número de complicações não imunes foi observado em pacientes sem rejeição. Os resultados sugerem que novos pontos de corte de MLVI devam ser explorados na população adulta.

Descritores: Transplante de Fígado; Tacrolimo; Rejeição ao Enxerto.

\section{REFERENCES}

1. Azzam AZ. Liver transplantation as a management of hepatocellular carcinoma. World J Hepatol. 2015;10(7):134754.

2. Associação Brasileira de Transplante de órgãos. Registro brasileiro de transplantes [Internet]. [citado 15 de outubro de 2018]. Available at: http://www.abto.org.br/abtov03/Upload/ file/RBT/2018/rbt2018-1-populacao.pdf

3. Adam R, Hoti E. Liver transplantation: the current situation. Semin Liver Dis. 2009;29(1):3-18.

4. Eaton CK, Gutierrez-colina AM, Quast LF, Liverman R, Harm PD, Lee JL, et al. Multimethod Assessment of Medication Nonadherence and Barriers in Adolescents and Young Adults With Solid Organ Transplants. J Pediatr Psychol. 2018;43(7):789-99.

5. Comissão Nacional de Incorporação de Tecnologias do SUS. Protocolo clínico e diretrizes terapêuticas, imunossupressão no transplante hepático em adultos. Relatório de Recomendação, 2016. [Internet]. [citado 15 de outubro de 2018]. Available at: http://conitec.gov. br/images/Consultas/Relatorios/2016/Relatorio_PCDT_ ImunossupressaoTransplanteHepatico_CP_2016_v2.pdf

6. Cruvinel WDM, Júnior DM, Antônio J, Araújo P, Tieko T, Catelan T. Sistema Imunitário - Parte I Fundamentos da imunidade inata com ênfase nos mecanismos moleculares e celulares da resposta inflamatória. Rev Bras Reumatol. 2010;50(4):434-61.
7. Drent G, Moons P, Geest S De, Kleibeuker JH, Haagsma EB. Symptom experience associated with immunosuppressive drugs after liver transplantation in adults : possible relationship with medication noncompliance? Clin Transplant. 2008;22(6):700-9.

8. Martin P, Dimartini A, Feng S, Brown R, Fallon M. Evaluation for Liver Transplantation in Adults: 2013 Practice Guideline by the American Association for the Study of Liver Diseases and the American Society of Transplantation. Hepatology. 2014;59(3):1144-65.

9. Xu M-M, Jr RSB. Liver Transplantation for the Referring Physician. Clin Liver Dis. 2015;19(1):135-53.

10. Molmenti E, Mazariegos G, Bueno J, Cacciarelli T, Alasio T, Khanna A, et al. Noncompliance After Pediatric Liver Transplantation. Transplant Proc. 1999;31(1):408.

11. Pollock-BarZiv SM, Finkelstein $Y$, Manlhiot $C$, Dipchand Al, Hebert D, Ng VL, et al. Variability in tacrolimus blood levels increases the risk of late rejection and graft loss after solid organ transplantation in older children. Pediatr Transplant. 2010;14(1):968-75.

12. Rodrigue J, Nelson D, Hanto D, Reed A, Curry M. Patient-reported immunosuppression nonadherence 6 to 24 months after liver transplant: Association with pretransplant psychosocial factors and perceptions of health status change. Prog Transplant. 2013;23(4):319_ 28. 
13. Shemesh E, Shneider BL, Savitzky JK, Arnott L, Gondolesi GE, Krieger NR, et al. Medication Adherence in Pediatric and Adolescent Liver Transplant Recipients. 2004;113(4):825-32.

14. Stuber ML, Shemesh E, Seacord D, III JW, Hellemann G, McDiarmid S. Evaluating non-adherence to immunosuppressant medications in pediatric liver transplant recipients. Pediatr Transplant. 2008;12(3):284-8.

15. Supelana C, Annunziato R, Schiano T, Anand R. The Medication Level Variability Index (MLVI) predicts rejection, possibly due to nonadherence, in adult liver transplant recipients. Liver Transplant. 2014;20(10):1168-77.

16. Venkat VL, Nick TG, Wang Y, Bucuvalas JC. An objective measure to identify pediatric liver transplant recipients at risk for late allograft rejection related to non-adherence. Pediatr Transplant. 2008;12(1):67-72.

17. Lin Xu 1, Ming-Qing Xu, Lu-Nan Yan, Bo Li, Tian-Fu Wen, Wen-Tao Wang. Causes of mortality after liver transplantation: a single center experience in mainland China. Hepatogastroenterology. 2012;114(59):481-4.

18. Xu MM, Brown RS. Liver transplantation for the referring physician. Clin Liver Dis. 2015;19(1):135-53.

19. Russell CL, Cetingok M, Hamburger KQ, Owens S, Thompson D, Hathaway D, et al. Medication Adherence in Older Renal Transplant Recipients. Clin Nurs Res. 2010;19(2):95-112.

20. Leven EA, Annunziato R, Helcer J, Lieber SR, Christopher S. Knight, Catherine Wlodarkiewicz RPS, S. SF, et al. Medication adherence and rejection rates in older versus younger adult liver transplant recipients. Clin Transplant. 2017;31(6):1-15.

21. Shemesh E, Bucuvalas JC, Anand R, Mazariegos GV, Estella M. The Medication Level Variability Index (MLVI) Predicts Poor Liver Transplant Outcomes A Prospective Multi-Site Study. Am J Transplant. 2017;17(10):2668-78.

22. Eaton CK, Gutierrez-colina AM, Quast LF, Liverman R, Lee $\mathrm{JL}$, Mee LL, et al. Multimethod Assessment of Medication Nonadherence and Barriers in Adolescents and Young Adults With Solid Organ Transplants. J Pediatr Psychol. 2018;43(7):789-99.
23. Oliveira JTP, Kieling CO, Silva AB, Stefani J, Witkowski MC, Smidt CR, et al. Variability index of tacrolimus serum levels in pediatric liver transplant recipients younger than 12 years : Non- adherence or risk of non- adherence ? Pediatr Transplant. 2017;21(e13058):1-6.

24. Araujo A, Valenzuela-Granados, Lopes AB. Sofosbuvirbased antiviral therapy in patients with recurrent HCV infection after liver transplant: A real-life experience. Ann Hepatol. 2019;18(3):450-5.

25. Saxena V, Khungar V, Verna EC. Safety and efficacy of current direct-acting antiviral regimens in kidney and liver transplant recipients with hepatitis C: Results from the HCVTARGET study. Hepatology. 2017;66(4):1090-101.

26. Schweizer RT, Rovelli M, Palmeri D. Noncompliance in organ transplant recipients. Transplantation. 1990;49(2):374-7.

27. Greenstein S1, Siegal B. Compliance and noncompliance in patients with a functioning renal transplant: a multicenter study. Transplantation. 1998;66(12):1718-26.

28. Adam R, McMaster P, G.O'Grady J, Castaing D, L. Klempnaue J, Jamieson N, et al. Evolution of liver transplantation in Europe: report of the European Liver Transplant Registry. Liver Transplant. 2003;9(12):1231-43.

29. Fink, A.S., Brown R. Liver transplantation: Indications, preoperative evaluation and posttransplantation management. In: Clinical Hepatology. Springer; 2009. p. 1353-81.

30. Wright TL, Donegan E,Hsu H, Ferrell L, Lake JR, Kim M, et al. Recurrent and acquired hepatitis $C$ viral infection in liver transplant recipients. Gastroenterology. 1992;103(1):317-22.

31. McDiarmid SV, Anand R, Lindblad AS. Studies of pediatric liver transplantation: 2002 update. An overview of demographics, indications, timing, and immunosuppressive practices in pediatric liver transplantation in the United States and Canada. Pediatr Transpl. 2004;8(3):284-94.

32. Merion R. Current status and future of liver transplantation. Semin Liver Dis. 2010;30(4):411-21.

33. Burra P, Ferrarese A, Feltrin G. Quality of life and adherence in liver transplant recipients. Minerva Gastroenterol Dietol. 2017;64(2):180-6. 